\title{
Enrichment of Organic Carbon in Sediment Transport by Interrill and Rill Erosion Processes
}

\author{
W. Schiettecatte \\ D. Gabriels* \\ W. M. Cornelis \\ G. Hofman \\ Department of Soil Management and Soil Care \\ Ghent Univ. \\ Coupure Links 653 \\ B-9000 Ghent \\ Belgium
}

\begin{abstract}
Erosion and loss of organic carbon (OC) result in degradation of the soil surface. Rill and interrill erosion processes on a silt loam soil were examined in laboratory rainfall and flume experiments. These experiments showed that rill and interrill erosion processes have contrasting impacts on enrichment of OC in transported sediment. Rill erosion was found to be nonselective, while for interrill erosion the enrichment ratio of $\mathrm{OC}, \mathrm{ER}_{\mathrm{OC}}$, varied between 0.9 and 2.6 and was inversely related to the unit sediment discharge. At unit sediment discharge values $>0.0017 \mathrm{~kg} \mathrm{~s}^{-1} \mathrm{~m}^{-1}$, the $\mathrm{ER}_{\mathrm{OC}}$ remained equal to 1 . The enrichment process was not influenced by raindrop impact. Enrichment of OC by "aggregate stripping" was found to be unimportant in our study. This was attributed to the low aggregate stability of the soil and the equal distribution of OC within the different soil aggregate classes.
\end{abstract}

Abbreviations: Ek, kinetic energy of the rain on the soil surface; ER, enrichment ratio; OC, organic carbon; qs, unit sediment discharge.
So oil losses by overland flow can remove a significant portion of biologically active organic matter, because a large part of the organic matter is located on or near the soil surface. Consequently, soil erosion decreases the chemical and physical soil fertility, affecting soil productivity (Williams, 1981). Although the erosional loss of nutrients can be replaced by fertilizers, the loss of organic $\mathrm{C}$ (OC) is not easily restored. Furthermore, OC is more important in terms of soil physical characteristics like porosity and aggregate stability (Le Bissonnais and Arrouays, 1997; Rhoton et al., 2002). Fullen (1991) found that a decline in soil organic matter to less than about $2 \%$ makes soils especially vulnerable to erosion. Furthermore, the OC loss by erosion affects nutrient availability both directly by loss of associated nutrients and indirectly by loss of cation exchange capacity. Erosion may result in decreased biomass production, which in turn adversely affects C storage in the soil because of the reduced quantity of OC returned to the soil as plant residues (Gregorich et al., 1998).

Total soil loss by erosion is the result of different processes such as deposition, splash, and interrill, rill, and gully erosion. These processes can cause a preferential transport of OC. Ghadiri and Rose (1991a) found that the outer layers of soil aggregates contained more $\mathrm{N}$, organic matter, and pesticides than the inner core. Therefore, "stripping" of the aggregates by raindrop impact caused an enrichment of these soil com-

Soil Sci. Soc. Am. J. 72:50-55

doi:10.2136/sssaj2007.0201

Received 4 June 2007.

*Corresponding authors (donald.gabriels@UGent.be).

(c) Soil Science Society of America

677 S. Segoe Rd. Madison WI 53711 USA

All rights reserved. No part of this periodical may be reproduced or transmitted in any form or by any means, electronic or mechanical, including photocopying, recording, or any information storage and retrieval system, without permission in writing from the publisher. Permission for printing and for reprinting the material contained herein has been obtained by the publisher. ponents in the eroded material. Most research has shown that the enrichment of OC in suspended sediment is related to a selective transport of clay particles, indicating that the enrichment mechanism is mainly controlled by the transport capacity of overland flow (e.g., Sharpley, 1985; Weigand et al., 1998). Enrichment of OC can also be caused by deposition: large particles and aggregates settle out more quickly, resulting in a physical enrichment of smaller particles and less dense aggregates in runoff (Davis et al., 1983; Lu et al., 1988; Beuselinck, 1999).

The selectivity of the erosion processes is often expressed as an enrichment ratio, ER (Massey and Jackson, 1952), calculated as the ratio of the concentration of a soil constituent in the eroded material to its concentration in the original soil. The enrichment ratio of $\mathrm{OC}, \mathrm{ER}_{\mathrm{OC}}$, has been related to $\mathrm{OC}$ content in the topsoil (Young and Onstad, 1976; Avnimelech and McHenry, 1984) and to soil loss (Sharpley, 1985; Ghadiri and Rose, 1991b). In general, $\mathrm{ER}_{\mathrm{OC}}$ values in suspended sediment have been found to be $>1$. For a sandy loam soil, Cogle et al. (2002) reported $\mathrm{ER}_{\mathrm{OC}}$ values between 1.3 and 4.1, with larger variations in $\mathrm{ER}_{\mathrm{OC}}$ at low sediment yields. Jacinthe et al. (2002) conducted laboratory rainfall simulations on small soil pans with undisturbed samples from fields under different tillage techniques. For no-till, moldboard plow, and chisel till, they reported $\mathrm{ER}_{\mathrm{OC}}$ values of $1.4,1.7$, and 2.3 at sediment delivery rates of $17.4,34.1$, and $48.9 \mathrm{~g} \mathrm{~m}^{-2} \mathrm{~h}^{-1}$, respectively. This indicates an increase in the $\mathrm{ER}_{\mathrm{OC}}$ with increasing soil loss rate, which is rather unusual and may be a result of the difference in tillage technique; however, the results of Cogle et al. (2002) indicated that the kind of tillage technique affected the sediment yields but did not directly influence the $\mathrm{ER}_{\mathrm{OC}}$. This was also observed by Basic et al. (2002) and Kisic et al. (2002) for enrichment of clay and OC, respectively. On the other hand, Fullen (1991) and Fullen et al. (1996) found lower OC, clay, and silt concentrations in eroded material compared with the loamy sand topsoil and attributed it to eluviation of clay and organic matter into the topsoil during runoff events. This in-washing process resulted in a "filtration pavement" immediately beneath the surface crust. 
The enrichment in OC is also affected by the storm intensity. The results of Jacinthe et al. (2004) suggest a more selective detachment and sorting of labile OC fractions during low-intensity storms than high-intensity storms. They stated that the high soil losses associated with intense rainstorms can determine the overall impact of erosional events on losses of labile OC. On the other hand, field plot experiments conducted by Quinton et al. (2001) showed that the enrichment of sediment during small events should not be neglected in estimating the loss of soil constituents by erosion.

The cited research results indicate that, in general, suspended sediment is enriched in OC. To what extent different erosion processes account for this enrichment mechanism, however, is still unclear. This knowledge is required for modeling OC losses. Polyakov and Lal (2004a) concluded in their review that only a few soil organic matter models incorporate an erosion component in their routine. These erosion components are based on empirical models like the Universal Soil Loss Equation, and are mostly unable to represent erosioninduced soil organic matter loss and deposition as spatially and temporally distributed phenomena. Erosion and deposition processes are dependent on spatially variable factors. Therefore, assessment of total soil loss in a lumped way does not take into account the spatial variation in enrichment processes. Moreover, many models use constant values for ER or (usually logarithmic) equations that relate ER to average soil loss during a rainfall event or a whole year. In this way, the effect of temporal variations in erosion intensity on the ER is not taken into account.

The purpose of this study was to examine the enrichment of OC caused by rill and interrill erosion processes simulated in the laboratory. Flume experiments and rainfall simulations were conducted on small soil pans to find a relationship between OC losses and erosion. Based on these experiments, also the influence of rainfall impact and interrill and rill erosion on $\mathrm{ER}_{\mathrm{OC}}$ was investigated. In this study, we only considered suspended material in runoff. Therefore, the term sediment refers to suspended sediment and not deposited material.

\section{MATERIALS AND METHODS General Setup}

For all the laboratory experiments, topsoil samples (0- to $0.05-\mathrm{m}$ depth) were taken from field plots located on a silt loam soil at Maarkedal, Belgium (50 $\left.46^{\prime} 29^{\prime \prime} \mathrm{N}, 3^{\circ} 35^{\prime} 11^{\prime \prime} \mathrm{E}\right)$. The field was moldboard plowed to the depth of $0.25 \mathrm{~m}$, followed by harrowing before planting. The particle size distribution of the soil obtained using fulldispersion and minimal-dispersion techniques is given in Table 1 . The soil has a $\mathrm{pH}(\mathrm{KCl})(1: 2.5 \mathrm{w} / \mathrm{w})$ of 5.4 and does not contain $\mathrm{CaCO}_{3}$. The OC content is $11 \mathrm{~g} \mathrm{~kg}^{-1}$.

Interrill and rill erosion have different driving forces: in interrill erosion, the interaction of rainfall impact and overland flow is important, while the main agent in rill erosion is overland flow. Therefore, a different setup was used for the two experiments: interrill erosion was examined by rainfall simulations, while rill erosion was mainly investigated by overland flow experiments.

\section{Interrill Erosion Experiments}

The soil was air dried and ground $(<8 \mathrm{~mm})$ before use in the experiments. The sieved soil was spread out equally in soil pans $(0.55$ $\mathrm{m}$ long, $0.20 \mathrm{~m}$ wide, and $0.035 \mathrm{~m}$ deep) and slightly compacted with a wooden plate to obtain a bulk density of $1.33 \mathrm{Mg} \mathrm{m}^{-3}$, equaling the conditions of the field plots at Maarkedal. Each soil pan had a perforated bottom, allowing free drainage of percolating water. The soil pans were set at slopes of 10 and $30 \%$.

To examine the influence of rainfall kinetic energy on the ER, a plastic cover was applied: small plastic sheets $(20$ by $20 \mathrm{~mm})$ were placed on wooden toothpicks, which were put into the soil according to an alternating grid based pattern, leaving $10-\mathrm{mm}$ space between the plastic cover and the soil surface. The use of plastic sheets with known dimensions allowed an accurate measurement of the covered area and better resembled the natural cover of germinating plants compared to mesh screens. The following surface covers were applied: $0,0.25,0.40,0.50,0.75$, and $0.9 \mathrm{~m}^{2} \mathrm{~m}^{-2}$. The kinetic energy of the rain on the soil surface, $\mathrm{Ek}\left(\mathrm{J} \mathrm{m}^{-2} \mathrm{~s}^{-1}\right)$, was calculated by multiplying the kinetic energy of the rain $\left(\mathrm{J} \mathrm{m}^{-2} \mathrm{~s}^{-1}\right)$ by the fraction of uncovered soil surface $\left(\mathrm{m}^{2} \mathrm{~m}^{-2}\right)$.

The experiments were done using two different kinds of rainfall simulators to have a wider range of rainfall intensities and rainfall kinetic energies. In the first series of experiments, a rainfall simulator with capillary tubes was used. The water level above the capillary tubes determined the rainfall intensity. Two different water levels were used, resulting in intensities of $25 \pm 5$ and $40 \pm 5 \mathrm{~mm} \mathrm{~h}^{-1}$, respectively. The diameter of the raindrops was $4.92 \pm 0.12 \mathrm{~mm}$ and their fall height was $2.75 \mathrm{~m}$. The nomograph constructed by Laws (1941) was used to estimate the terminal velocity of the drops. The calculation of the rainfall kinetic energy was based on the normal velocity of raindrop impact. The rainfall intensities of 25 and $40 \mathrm{~mm} \mathrm{~h}^{-1}$ provided rainfall kinetic energies of 0.15 and $0.23 \mathrm{~J} \mathrm{~m}^{-2} \mathrm{~s}^{-1}$, respectively. More details about the rainfall simulator were given by Gabriels et al. (1973). Rainfall intensities were kept constant during the experiments, which lasted for $100 \mathrm{~min}$. The first runoff sample was taken after $20 \mathrm{~min}$; afterward, sampling was done every $10 \mathrm{~min}$. Runoff volume was measured and analyzed for sediment content. During the second half of the experiment, a steady runoff and sediment discharge was obtained. Rainfall simulations at $40 \mathrm{~mm} \mathrm{~h}^{-1}$ indicated that the ER of the suspended sediment reached a steady state when sediment discharge became constant (Schiettecatte, 2006). Therefore, only the runoff sampled at the end of the experiment was used to analyze the OC content in the sediment.

To provide higher rainfall intensities (and consequently higher runoff discharges), the rainfall simulator in the ICE wind tunnel (International Centre for Eremology, Ghent University, Ghent, Belgium) was used. A detailed description of the wind tunnel was given by Gabriels et al. (1997) and Cornelis et al. (2004a). Instead of using capillary tubes, the rainfall was simulated by pressurized nozzles (type TeeJet TG SS $14 \mathrm{w}$ ), fixed at a height of $1.8 \mathrm{~m}$. A nozzle pressure of $1.5 \times 10^{5} \mathrm{~Pa}$ was applied. The kinetic energy was determined

Table 1. Fully dispersed and minimally dispersed particle size distribution of the silt loam soil used in the experiments.

\begin{tabular}{lcc}
\multicolumn{1}{c}{ Fraction } & Fully dispersed & \multicolumn{2}{c}{ Minimally dispersed } \\
\cline { 2 - 3 }$\mu \mathrm{m}$ & 170 & $\mathrm{~g} \mathrm{~kg}^{-1}$ \\
$0-2$ & 48 & 74 \\
$2-10$ & 112 & 108 \\
$10-20$ & 380 & 111 \\
$20-50$ & 135 & 437 \\
$50-100$ & 128 & 110 \\
$100-200$ & 20 & 128 \\
$200-500$ & 7 & 24 \\
$500-2000$ & & 8 \\
\hline
\end{tabular}


indirectly using the splash-cup technique (Ellison, 1947; Salles and Poesen, 2000; Salles et al., 2000; Cornelis et al., 2004b,c). Because the median diameter of the raindrops produced by the nozzles was only $1 \mathrm{~mm}$, the kinetic energy of the raindrops was much lower than the simulator with the capillary tubes. The rainfall simulation experiments lasted for $30 \mathrm{~min}$, with a rainfall intensity of $70 \mathrm{~mm} \mathrm{~h}^{-1}$ and a rainfall kinetic energy of $0.035 \mathrm{~J} \mathrm{~m}^{-2} \mathrm{~s}^{-1}$ for conditions in which one nozzle was used. When two nozzles were used (at 1-m distance from each other), an intensity of $120 \mathrm{~mm} \mathrm{~h}^{-1}$ with a rainfall kinetic energy of $0.079 \mathrm{~J} \mathrm{~m}^{-2} \mathrm{~s}^{-1}$ was applied for $20 \mathrm{~min}$. Every $2 \mathrm{~min}$, the runoff volume was measured and analyzed for sediment content. The runoff sampled at the end of the experiment was used to determine the OC content in the sediment.

The combination of two slopes, six different covers, and four different intensities resulted in a total of 48 experiments.

\section{Rill Erosion Experiments}

\section{Rill Experiment 1: Addition of Water to a Preformed Erodible Gully}

A soil pan (0.96 m long, $0.56 \mathrm{~m}$ wide, and $0.20 \mathrm{~m}$ deep) was filled with air-dried soil aggregates $(<8 \mathrm{~mm})$ to obtain a bulk density of $1.33 \mathrm{Mg} \mathrm{m}^{-3}$. An artificial V-shaped rill was made with slopes of $30 \%$ at both sides. The soil pan was placed at slopes of 10, 20, and $30 \%$. Sediment-free tap water was added at a constant discharge of 0.01 and $0.017 \mathrm{~L} \mathrm{~s}^{-1}$ at the upper edge of the rill. Runoff volume was measured and analyzed for sediment content every $60 \mathrm{~s}$ for the low discharge and every $30 \mathrm{~s}$ for the high discharge. At the end of the experiment, one more runoff sample was taken to determine OC content. Every experiment lasted for 5 or 10 min depending on the high or low runoff discharge. At the end of the experiments, the rill width was measured for calculation of the sediment discharge per unit width.

\section{Rill Experiment 2: Addition of Water and Sediment to a Preformed Erodible Gully}

A similar setup (same slopes and soil pan configuration) was also used with dry soil aggregates $(<2 \mathrm{~mm})$ added to the water inflow, resulting in an average input sediment concentration of $163 \mathrm{~g} \mathrm{~L}^{-1}$. Sampling and measurements were done following the same procedure as described above.

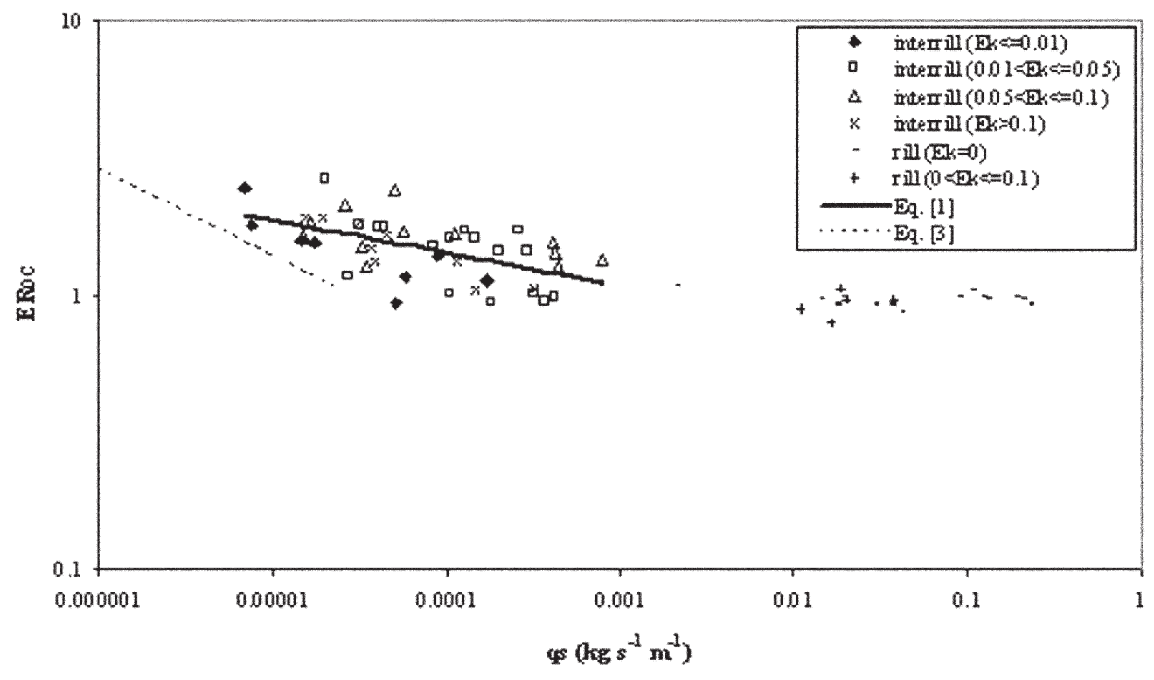

Fig. 1. The enrichment ratio of organic $C, E R_{O C}$, as a function of unit sediment discharge, qs, for different rainfall kinetic energies, Ek $\left(\mathrm{J} \mathrm{m}^{-2} \mathrm{~s}^{-1}\right)$, compared with Eq. [3], the relationship given by Sharpley (1985).

\section{Rill Experiment 3: Rainfall Simulation on a Preformed Erodible Gully}

An analogous experiment was done using the same soil pan configuration, but neither water nor sediment was added to the rill. Instead, rainfall simulations were done in the ICE wind tunnel, using intensities of $100 \mathrm{~mm} \mathrm{~h}^{-1}$. Kinetic energy of the rainfall was measured using the splash-cup technique. The soil pan was set at slopes of 10,20 , and $30 \%$. The rainfall simulations lasted for $30 \mathrm{~min}$ and runoff was sampled every $30 \mathrm{~s}$. At the end of the experiment, one more runoff sample was taken to determine OC content. At the end of the experiments, the rill width was measured for calculation of sediment discharge per unit width.

\section{Analysis of Samples and Data}

The sediment concentration of the runoff samples was determined by drying (at $105^{\circ} \mathrm{C}$ ), using tared recipients. The OC content was determined using the method of Walkley and Black (1934). Because this method yields, on average, $75 \%$ of the total OC, the results of the analysis were divided by 0.75 to obtain the total OC content (De Leenheer and Van Hove, 1958). The fully dispersed particle-size analysis was obtained using the sieve pipette method (De Leenheer, 1966). The minimally dispersed particle-size distribution was obtained in a similar way without chemically dispersing the samples.

Aggregate stability was determined by wet sieving according to the procedure of De Leenheer and De Boodt (1959), using a fixed aggregate-size distribution with a mean weight diameter (MWD) of $4.45 \mathrm{~mm}$. Briefly, the soil aggregates were prewetted by raindrops and incubated for $24 \mathrm{~h}$. After wet sieving for $5 \mathrm{~min}$, the MWD of the resulting aggregate size distribution was determined. The stability index was calculated as the reciprocal value of the difference between the original MWD $(4.45 \mathrm{~mm})$ and the MWD of the wet-sieved soil sample. After wet sieving and drying $\left(\right.$ at $\left.105^{\circ} \mathrm{C}\right)$, the $\mathrm{OC}$ content of the different aggregate size fractions $(0.3-0.5,0.5-1.0,1.0-2.0$, $2.0-2.8,2.8-4.8$, and $4.8-8.0 \mathrm{~mm}$ ) was determined.

Unless stated otherwise, the ER of a soil constituent was calculated by dividing the content of the constituent in the suspended sediment by its content in the original soil material. Analysis of variance and regression analysis were done using the statistical software SPSS Version 11.0.1 (SPSS, 2001).

\section{RESULTS AND DISCUSSION Interrill Erosion}

In Fig. 1, the $\mathrm{ER}_{\mathrm{OC}}$ is shown as a function of the unit sediment discharge, qs, measured during the last sampling interval of both the interrill and rill erosion experiments. For the interrill erosion experiments, the $\mathrm{ER}_{\mathrm{OC}}$ values varied between 0.93 and 2.61, with an average value of 1.53 , while qs ranged between 6.8 and $790 \mathrm{mg} \mathrm{s}^{-1} \mathrm{~m}^{-1}$, with an average of $140 \mathrm{mg} \mathrm{s}^{-1} \mathrm{~m}^{-1}$. It can be observed that the $\mathrm{ER}_{\mathrm{OC}}$ decreased with an increase in qs. Higher sediment transport rates will decrease the selectivity of the erosion process, as larger aggregates and particles are also transported. This is supported by findings of Olarieta et al. (1999), who observed that on steep slopes the eroded 
material was not significantly enriched in organic matter or nutrients due to the high erosive power of the runoff.

When correlating $\mathrm{ER}_{\mathrm{OC}}$ to qs, we found a Pearson $r$ value of -0.425 , which was significant at the 0.01 level. Apart from qs, raindrop impact is expected to be the most important variable that might control the enrichment mechanism. For ER $\mathrm{OC}_{\mathrm{O}}$ vs. Ek, however, a Pearson $r$ of only -0.028 was found, which was not significant at the 0.01 level. This was further confirmed by a stepwise linear regression on log-transformed data showing that only qs had a significant influence on the $\mathrm{ER}_{\mathrm{OC}}$. The hence obtained regression equation, which was significant at the 0.01 level despite the rather low $r$ value $(r=0.574)$, was

$$
\mathrm{ER}_{\mathrm{OC}}=0.455 \mathrm{qs}^{-0.123}
$$

where $\mathrm{ER}_{\mathrm{OC}}$ is the enrichment ratio of $\mathrm{OC}$ and qs is unit sediment discharge $\left(\mathrm{kg} \mathrm{s}^{-1} \mathrm{~m}^{-1}\right)$.

In conducting laboratory rainfall simulations on small soil pans $(0.3$ by $0.45 \mathrm{~m})$ but with a rainfall intensity of $30 \mathrm{~mm} \mathrm{~h}^{-1}$, Jacinthe et al. (2002) found, for undisturbed samples from moldboard-plowed plots, $\mathrm{ER}_{\mathrm{OC}}$ values close to 1.7 for qs rates of 3.7 and $4.9 \mathrm{mg} \mathrm{s}^{-1} \mathrm{~m}^{-1}$. Although these qs values are outside the range of our observations, the $\mathrm{ER}_{\mathrm{OC}}$ values measured by Jacinthe et al. (2002) seem to be slightly lower than expected based on our observations.

Several (usually logarithmic) relationships have been given to predict ER values from soil loss data (e.g., Menzel, 1980). These are difficult to compare with Eq. [1] and the results in Fig. 1, however, as soil loss is usually expressed in kilograms per hectare. Rescaling soil losses from experimental plot areas to hectares may produce different results because of differences in plot width. Moreover, soil loss expressed in kilograms per hectare does not indicate the intensity of the erosion process because no time component is included. Low-intensity rainfall for a long period may cause as much erosion as a short, intense rainfall event, but enrichment processes will be different in the two cases. Weigand et al. (1998) found that for the same soil loss of $60 \mathrm{~kg} \mathrm{ha}^{-1}$, the ER values of ${ }^{137} \mathrm{Cs}$ varied between 0.51 and 2.46. Therefore, the applicability of an ER in models that assess soil loss on a long-term (annual) basis can be questioned, especially if the runoff events for a longer period show large variations in erosion intensities.

The reason for using unit sediment discharge, qs $\left(\mathrm{kg} \mathrm{s}^{-1} \mathrm{~m}^{-1}\right)$, which is the sediment transport per unit width and unit time, rather than soil loss $\left(\mathrm{kg} \mathrm{ha}^{-1}\right)$, in Eq. [1] is that it is a better expression for "erosion intensity" and can also be measured easily during experiments. Furthermore, qs is commonly used in sediment transport equations, relating runoff to erosion (e.g., Nearing et al., 1997). Equation [1] enables linking nutrient losses to runoff and sediment transport, which is of particular interest in the case of event-based modeling.

Despite the difficulties in comparing data due to the different expressions of soil loss, we verified our results with a relationship given by Sharpley (1985), who related the $\mathrm{ER}_{\mathrm{OC}}$ to soil loss $\left(\mathrm{kg} \mathrm{ha}^{-1}\right)$ for different soil types. For a Durant soil, which has similar textural properties as the soil in our study, he found

$$
\mathrm{ER}_{\mathrm{OC}}=8.943(\text { soil loss })^{-0.317}
$$

To verify our results with Eq. [2], the soil loss value in Eq. [2] was converted into unit sediment discharge, qs $\left(\mathrm{kg} \mathrm{s}^{-1} \mathrm{~m}^{-1}\right)$, taking into account the experimental setup used by Sharpley (1985), i.e., 60-min rainfall simulations on soil pans of 1-m length and 0.3-m width. Equation [2] can hence be rewritten as

$$
\mathrm{ER}_{\mathrm{OC}}=0.036 \mathrm{qs}^{-0.317}
$$

As illustrated in Fig. 1, Eq. [3] predicts lower ER OC $_{\text {values }}$ for our measurement range than Eq. [1]. Sharpley (1985) worked with pans with a lower slope, on slowly prewetted samples, which may partly explain the difference in results. Because slaking does not occur in slowly prewetted samples, the soil used by Sharpley (1985) was less susceptible to complete aggregate breakdown than dry samples directly exposed to rain as reported in this study. This is also reflected in the differences in sediment discharge between Sharpley's study and ours. Sharpley (1985) observed soil losses ranging between 10 and $800 \mathrm{~kg} \mathrm{ha}^{-1}$, or 0.278 and $24 \mathrm{mg} \mathrm{m}^{-1} \mathrm{~s}^{-1}$, respectively, when converted to unit sediment discharge. In our experiments, the unit sediment discharge values ranged from 6.8 to $790 \mathrm{mg} \mathrm{m}^{-1} \mathrm{~s}^{-1}$. These findings indicate that relationships between ER and soil loss may vary not only for various soil types but also across different soil loss ranges.

To further validate our findings, we used data published by Polyakov and Lal (2004b). They conducted rainfall simulations on small soil pans $(0.3 \mathrm{~m}$ wide and $1 \mathrm{~m}$ long $)$ filled with sieved $(<8-\mathrm{mm})$ silt loam soil. Four soil pans were positioned in a cascade system in which runoff from the upper soil pan flowed into the lower pan. A subsample of the runoff from each soil pan was taken at regular time intervals and analyzed for sediment and OC content. The subsequent pans were put under different slopes $(8,7,1$, and $0.5 \%)$, resembling a concave hillslope. This setup resulted in erosion on the 8 and $7 \%$ slopes, of which the sediment was partly deposited on the $1 \%$ slope. Because deposition is a different enrichment process

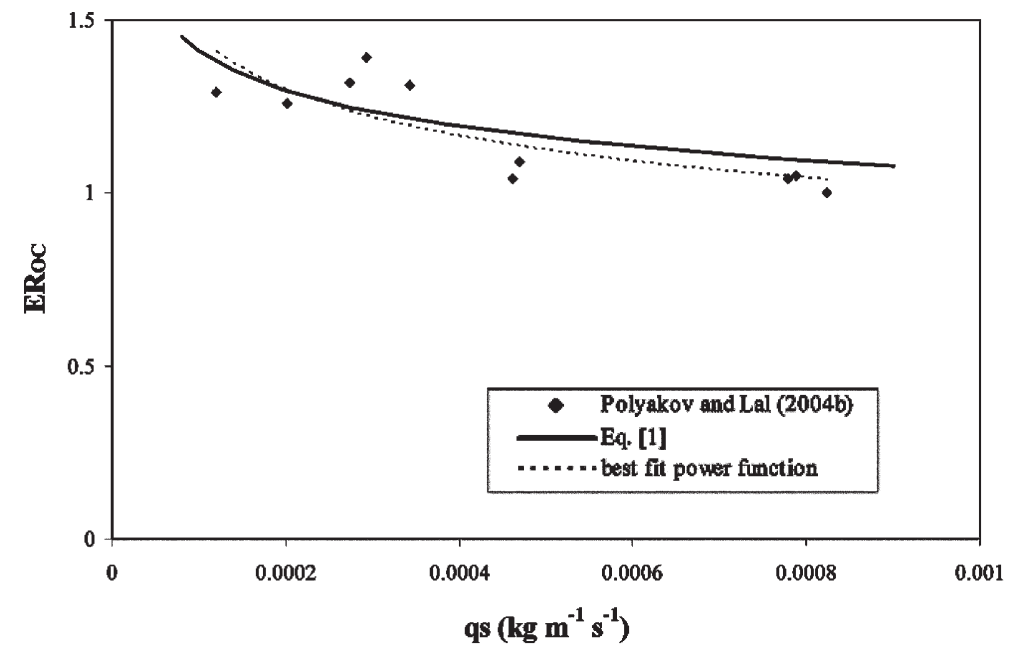

Fig. 2. Relationship between enrichment ratio of organic $C, \mathrm{ER}_{\mathrm{OC}}$, and unit sediment discharge, qs, for the data of Polyakov and Lal (2004b) compared with Eq. [1]. 
Table 2. Concentration of organic $C$ in different aggregate size classes obtained after wet sieving $(n=5$; values in parentheses indicate standard deviations).

\begin{tabular}{cc} 
Aggregate class & Organic C \\
\hline $\mathrm{mm}$ & $\mathrm{g} \mathrm{kg}^{-1}$ \\
$0.3-0.5$ & $12(1)$ \\
$0.5-1.0$ & $11(1)$ \\
$1.0-2.0$ & $10(1)$ \\
$2.0-2.8$ & $11(1)$ \\
$2.8-4.8$ & $10(1)$ \\
$4.8-8.0$ & $10(1)$ \\
\hline
\end{tabular}

than interrill erosion, we only used the data from the 8 and $7 \%$ slopes to validate our findings. As shown in Fig. 2, the observations of Polyakov and Lal (2004b) agree well with ours: the best-fit power function for the data in Fig. 2 closely resembles Eq. [1]. Polyakov and Lal (2004b) further found that the ER decreased with rainfall duration. They attributed the higher $\mathrm{ER}_{\mathrm{OC}}$ values during the initial stage of the rainfall experiment to a flushing of loose organic particles and fine soil fractions. Based on Fig. 2, we may conclude that the higher $\mathrm{ER}_{\mathrm{OC}}$ values are a result of the lower qs values. Due to the lower transport capacity of the runoff, a selective transport of small particles rich in $\mathrm{OC}$ occurs.

Not only in laboratory experiments, but also at the field scale, several researchers have revealed a relationship between erosion rate and $\mathrm{ER}_{\mathrm{OC}}$. Using field rainfall simulations on silt loam and loamy soils, Young et al. (1986) observed an increase in $\mathrm{ER}_{\mathrm{OC}}$ with decreasing soil loss: $\mathrm{ER}_{\mathrm{OC}}$ values varied between 1.41 and 2.21 for a soil loss range of 7.32 to $20.58 \mathrm{Mg} \mathrm{ha}^{-1}$. Lowrance and Williams (1988) also conducted field rainfall simulations and found that the suspended sediment under four-row peanut (Arachis hypogaea L.) cover was more enriched in OC than the sediment from a continuous fallow plot. This may be attributed to the lower soil losses from the covered plots, being less than half of the soil losses from the bare plots. Andreu et al. (1994) measured soil and nutrient losses on field plots under natural rainfall and observed that, with respect to the texture of the suspended sediment, all plots showed enrichment in clay. This phenomenon was more obvious for the plot without vegetation, which would indicate that cover may influence the ER. On the other hand, the enrichment in OC was, on average, lower on the bare plot than the vegetated plots, which was attributed to the accumulation of plant biomass on the vegetated plots. Furthermore, the ER may be influenced by the erosion intensity, because soil losses on the vegetated plots were always lower than on the bare plot. Consequently, the estimation of ER values from large field plots and watersheds is difficult due to the interaction of different enrichment processes and the larger within-field variability of OC.

Ghadiri and Rose (1991a) found that "stripping" of soil aggregates was the main mechanism in nutrient enrichment of eroded particles in the case of a well-aggregated soil. This was also confirmed by Wan and El-Swaify (1998) in the case of a well-aggregated Oxisol. The soil used in our experiments has a stability index of 0.36 , indicating a low aggregate stability. This is also confirmed by the particle size data (Table 1) showing a similar distribution for minimally dispersed and fully dispersed samples, except for the clay fraction, which was mainly aggregated to 2 - to $10-\mu \mathrm{m}$ sizes in the case of the samples that were minimally dispersed. The use of air-dried soil in the experiments may have enhanced the rapid breakdown of the aggregates, as dry aggregates are more susceptible to slaking and breakdown by rainfall impact than prewetted aggregates. Therefore "stripping" is considered to be an unimportant enrichment mechanism for this soil. If "stripping" would have been important, the $\mathrm{ER}_{\mathrm{OC}}$ should decrease with increasing Ek because of a more complete breakdown of the aggregates. This trend could not be observed in our results (Fig. 1), however, and Ek was found to be an insignificant variable in the stepwise regression analysis. Analysis of the OC content in the different aggregate fractions obtained after wet sieving did not show a significant increase in OC (at the 0.05 level) with decreasing aggregate size (Table 2). This indicates a rather homogeneous distribution of OC within the aggregates. This was also observed by Schiettecatte (2006) for the OC content and textural composition of different aggregate classes, which had been separated by dry sieving the same soil used in our study. Therefore, we can conclude that for the soil under study, detachment by raindrop impact is an unselective process. This agrees with the results of Gabriels and Moldenhauer (1978), who found that for different soil types (fine sand, silt loam, silty clay loam, and silty clay), the particle size distribution of detached material by splash erosion was not significantly different from that of the original soil.

\section{Rill Erosion}

The $\mathrm{ER}_{\mathrm{OC}}$ as a function of qs for the rill erosion experiments is given in Fig. 1 as well. The $\mathrm{ER}_{\mathrm{OC}}$ values ranged between 0.80 and 1.07 with an average of 0.95 , while qs ranged between 0.002 and $0.224 \mathrm{~kg} \mathrm{~s}^{-1} \mathrm{~m}^{-1}$, with an average of $0.07 \mathrm{~kg} \mathrm{~s}^{-1} \mathrm{~m}^{-1}$. Linear regression on log-transformed values of $\mathrm{ER}_{\mathrm{OC}}$ vs. qs for rill erosion showed that both the slope and intercept were not significantly different from 0 (at the 0.01 level), which indicates that the $\mathrm{ER}_{\mathrm{OC}}$ equals 1 regardless of the sediment discharge. This agrees with the general statement that interrill erosion causes selective transport of finer sediment particles and nutrients, while no selectivity is observed in sediment transport by rill erosion (Meyer et al., 1975; Alberts et al., 1980; Proffitt and Rose, 1991). When extrapolating Eq. [1] beyond the measured qs range of the interrill erosion experiments, $\mathrm{ER}_{\mathrm{OC}}$ becomes equal to 1 at a qs value of $1700 \mathrm{mg} \mathrm{s}^{-1} \mathrm{~m}^{-1}$. This value corresponds to the lowest qs values observed during the rill erosion experiments. For qs > $1700 \mathrm{mg} \mathrm{s}^{-1} \mathrm{~m}^{-1}$, Eq. [1] does not hold and $\mathrm{ER}_{\mathrm{OC}}=1$.

The results given in Fig. 1 further indicate that detachment by overland flow in rills is not influenced by raindrop impact. This is in agreement with the results of the interrill erosion experiments.

\section{CONCLUSIONS}

Laboratory experiments showed that enrichment of OC in suspended sediment is dependent on the erosion process. Rill erosion was found to be unselective, while $\mathrm{ER}_{\mathrm{OC}}$ values for interrill erosion decreased from 2.6 toward 1 as the erosion rate increased. At qs values $>1700 \mathrm{mg} \mathrm{s}^{-1} \mathrm{~m}^{-1}$, the $\mathrm{ER}_{\mathrm{OC}}$ remained equal to 1 . The enrichment process was not influenced by raindrop impact or "aggregate stripping." The trend in $\mathrm{ER}_{\mathrm{OC}}$ values indicated that the intensity of the erosion pro- 
cess has to be taken into account. Therefore, the use of a constant $\mathrm{ER}_{\mathrm{OC}}$ value, as is sometimes used in erosion modeling, is not in accordance with our observations. Relating the $\mathrm{ER}_{\mathrm{OC}}$ to the OC content of the soil or to the total soil loss, expressed as mass per area, also does not take into account the influence of erosion intensity on OC enrichment. The use of an average (annual) soil loss masks the variation in erosion rates occurring during runoff events and is therefore not a suitable variable to predict enrichment ratios and losses of OC.

\section{REFERENCES}

Alberts, E.E., W.C. Moldenhauer, and G.R. Foster. 1980. Soil aggregates and primary particles transported in rill and interrill flow. Soil Sci. Soc. Am. J. 44:590-595.

Andreu, V., J. Forteza, J.L. Rubio, and R. Cerni. 1994. Nutrient losses in relation to vegetation cover on automated field plots. p. 116-126. In R.J. Rickson (ed.) Conserving soil resources, European perspectives. CAB Int., Wallingford, UK

Avnimelech, Y., and J.R. McHenry. 1984. Enrichment of transported sediments with organic carbon, nutrients, and clay. Soil Sci. Soc. Am. J. 48:259-266.

Beuselinck, L. 1999. Sediment deposition by overland flow, an experimental and modelling approach. Ph.D. diss. Katholieke Univ. Leuven, Leuven, Belgium.

Basic, F., I. Kisic, O. Nestroy, M. Mesic, and A. Butorac. 2002. Particle size distribution (texture) of eroded soil material. J. Agron. Crop Sci. 188:311-322.

Cogle, A.L., K.P.C. Rao, D.F. Yule, G.D. Smith, P.J. George, S.T. Srinivasan, and L. Jangawad. 2002. Soil management for Alfisols in the semiarid tropics: Erosion, enrichment ratios and runoff. Soil Use Manage. 18:10-17.

Cornelis, W.M., G. Erpul, and D. Gabriels. 2004a. The I.C.E. wind tunnel for water and wind interaction research. p. 195-224. In S. Visser and W.M. Cornelis (ed.) Wind and rain interaction in erosion. Tropical Resour. Manage. Pap. 50. Wageningen Univ. and Res. Ctr., Wageningen, the Netherlands.

Cornelis, W.M., G. Oltenfreiter, D. Gabriels, and R. Hartmann. 2004b. Splash-saltation of sand due to wind-driven rain: Vertical deposition flux and sediment transport rate. Soil Sci. Soc. Am. J. 68:32-40.

Cornelis, W.M., G. Oltenfreiter, D. Gabriels, and R. Hartmann. 2004c. Splashsaltation of sand due to wind-driven rain: Horizontal flux and sediment transport rate. Soil Sci. Soc. Am. J. 68:41-46.

Davis, S.S., G.R. Foster, and L.F. Huggins. 1983. Deposition of nonuniform sediment on concave slopes. Trans. ASAE 26:1057-1063.

De Leenheer, L. 1966. Soil texture. p. 43-67. In H. Linser (ed.) Handbuch der Planzenernährung und-düngung. Band ii: Boden und Düngemittel. Springer-Verlag, New York.

De Leenheer, L., and M. De Boodt. 1959. Determination of aggregate stability by the change in mean weight diameter. Meded. Landbouwhogesch. Opzoekingsst. Staat Gent 24:290-300.

De Leenheer, L., and J. Van Hove. 1958. Détermination de la teneur en carbone organique des sols. Etude des méthodes titrimétriques. Pedologie 8:39-77.

Ellison, W.D. 1947. Soil erosion studies. Parts 1-7. J. Agric. Eng. 28:145-146, 197-201, 245-248, 297-300, 349-351, 407-408, 447-450.

Fullen, M.A. 1991. Soil organic matter and erosion processes on arable loamy sand soils in the west Midlands of England. Soil Technol. 4:19-31.

Fullen, M.A., Z. Yi, and R.T. Brandsma. 1996. Comparison of soil and sediment properties of a loamy sand soil. Soil Technol. 10:35-45.

Gabriels, D., W. Cornelis, I. Pollet, T. Van Coillie, and M. Ouessar. 1997. The ICE wind tunnel for wind and water erosion studies. Soil Technol. 10:1-8.

Gabriels, D., M. De Boodt, and W. Minjauw. 1973. Description of a rainfall simulator for soil erosion studies. Meded. Fac. Landbouwwet. Bijksuniv. Gent 38:294-303.

Gabriels, D., and W.C. Moldenhauer. 1978. Size distribution of eroded material from simulated rainfall: Effect over a range of texture. Soil Sci. Soc. Am. J. 42:954-958.

Ghadiri, H., and C.W. Rose. 1991a. Sorbed chemical transport in overland flow: I. A nutrient and pesticide enrichment mechanism. J. Environ. Qual. 20:628-633.

Ghadiri, H., and C.W. Rose. 1991b. Sorbed chemical transport in overland flow: II. Enrichment ratio variation with erosion processes. J. Environ. Qual. 20:634-641.

Gregorich, E.G., K.J. Greer, D.W. Anderson, and B.C. Liang. 1998. Carbon distribution and losses: Erosion and deposition effects. Soil Tillage Res. 47:291-302.

Jacinthe, P.A., R. Lal, and J.M. Kimble. 2002. Carbon dioxide evolution in runoff from simulated rainfall on long-term no-till and plowed soils in southwestern Ohio. Soil Tillage Res. 66:23-33.

Jacinthe, P.A., R. Lal, L.B. Owens, and D.L. Hothem. 2004. Transport of labile carbon in runoff as affected by land use and rainfall characteristics. Soil Tillage Res. 77:111-123.

Kisic, I., F. Basic, O. Nestroy, M. Mesic, and A. Butorac. 2002. Chemical properties of eroded soil material. J. Agron. Crop Sci. 188:323-334.

Laws, J.O. 1941. Measurements of the fall velocity of water drops and raindrops. Trans. Am. Geophys. Union 22:709-721.

Le Bissonnais, Y., and D. Arrouays. 1997. Aggregate stability and assessment of soil crustability and erodibility: 2. Application to humic loamy soils with various organic carbon contents. Eur. J. Soil Sci. 48:39-48.

Lowrance, R., and R.G. Williams. 1988. Carbon movement in runoff and erosion under simulated rainfall conditions. Soil Sci. Soc. Am. J. 52:1445-1448.

Lu, J.Y., E.A. Cassol, G.R. Foster, and W.H. Neibling. 1988. Selective transport and deposition of sediment particles in shallow flow. Trans. ASAE 31:1141-1147.

Massey, H.F., and M.L. Jackson. 1952. Selective erosion of soil fertility constituents. Soil Sci. Soc. Am. Proc. 16:353-356.

Menzel, R.G. 1980. Enrichment ratio for water quality modeling. p. 486-492. In W. Knisel (ed.) CREAMS: A field scale model for chemicals, runoff, and erosion from agricultural management systems. Conserv. Res. Rep. 26. USDA, Washington, DC.

Meyer, L.D., G.R. Foster, and S. Nikolov. 1975. Effect of flow-rate and canopy on rill erosion. Trans. ASAE 18:905-911.

Nearing, M.A., L.D. Norton, D.A. Bulgakov, G.A. Larionov, L.T. West, and K.M. Dontsova. 1997. Hydraulics and erosion in eroding rills. Water Resour. Res. 33:865-876.

Olarieta, J.R., G. Besga, R. Rodriguez, A. Uson, M. Pinto, and S. Virgel. 1999. Sediment enrichment ratios after mechanical site preparation for Pinus radiata plantation in the Basque country. Geoderma 93:255-267.

Polyakov, V., and R. Lal. 2004a. Modeling soil organic matter dynamics as affected by soil water erosion. Environ. Int. 30:547-556.

Polyakov, V., and R. Lal. 2004b. Soil erosion and carbon dynamics under simulated rainfall. Soil Sci. 169:590-599.

Proffitt, A.P.B., and C.W. Rose. 1991. Soil erosion processes: II. Settling velocity characteristics of eroded sediment. Aust. J. Soil Res. 29:685-695.

Quinton, J.N., J.A. Catt, and T.M. Hess. 2001. The selective removal of phosphorus from soil: Is event size important? J. Environ. Qual. 30:538-545.

Rhoton, F.E., M.J. Shipitalo, and D.L. Lindbo. 2002. Runoff and soil loss from midwestern and southeastern US silt loam soils as affected by tillage practice and soil organic matter content. Soil Tillage Res. 66:1-11.

Salles, C., and J. Poesen. 2000. Rain properties controlling soil splash detachment. Hydrol. Processes 14:271-282.

Salles, C., J. Poesen, and G. Govers. 2000. Statistical and physical analysis of soil detachment by raindrop impact: Rain erosivity indices and threshold energy. Water Resour. Res. 36:2721-2729.

Schiettecatte, W. 2006. Assessment of sediment and phosphorus transport from laboratory to watershed scale. Ph.D. diss. Ghent Univ., Ghent, Belgium.

Sharpley, A.N. 1985. The selective erosion of plant nutrients in runoff. Soil Sci. Soc. Am. J. 49:1527-1534.

SPSS. 2001. SPSS. Release Version 11.0.1. SPSS, Chicago, IL.

Walkley, A., and I.A. Black. 1934. An examination of the Degtjareff method for determining soil organic matter and a proposed modification of the chromic acid titration method. Soil Sci. 37:29-38.

Wan, Y., and S.A. El-Swaify. 1998. Sediment enrichment mechanisms of organic carbon and phosphorus in a well-aggregated Oxisol. J. Environ. Qual. 27:132-138.

Weigand, S., W. Schimmack, and K. Auerswald. 1998. The enrichment of Cs137 in the soil loss from small agricultural watersheds. Z. Pflanzenernaehr. Bodenkd. 161:479-484.

Williams, J.R. 1981. Soil erosion effects on soil productivity: A research perspective. J. Soil Water Conserv. 36:82-90.

Young, R.A., A.E. Olness, C.K. Mutchler, and W.C. Moldenhauer. 1986. Chemical and physical enrichments of sediment from cropland. Trans. ASAE 29:165-169.

Young, R.A., and C.A. Onstad. 1976. Predicting particle-size composition of eroded soil. Trans. ASAE 19:1071-1075. 